\title{
Response of Sweet Corn Hybrid to Establishment Methods and Weed Management Practices under Temperate Conditions
}

\author{
Shayista Fayaz ${ }^{1 *}$, Nazir Ahmad Teeli ${ }^{1}$, Ashaq Hussain ${ }^{1}$, Manzoor A. Ganai ${ }^{1}$, \\ Shakeel Ahmad Mir ${ }^{2}$ and Zahoor A. Baba ${ }^{3}$ \\ ${ }^{1}$ Mountain Research Centre for Field Crop (SKUAST-K), Khudwani, \\ Anantnag, (J\&K), 192 102, India \\ ${ }^{2}$ Division of Agri-Statistics, Faculty of Agriculture (SKUAST-K), Shalimar, \\ (J\&K), 190025, India \\ ${ }^{3}$ Division of Soil Science and Agricultural Chemistry, Faculty of Agriculture (SKUAST-K), \\ Wadura, Sopore (J\&K), 193201, India \\ *Corresponding author
}

\section{Keywords}

Direct seeding, Transplanting, Herbicide, Quality, Sweet corn, Yield

Article Info

Accepted:

12 January 2019

Available Online:

10 February 2019
A B S T R A C T

A field experiment on "Response of Sweet corn hybrid to establishment methods and weed management practices under temperate conditions" was conducted at research farm of Faculty of Agriculture (SKUAST-K) kharif during 2017. The treatments comprised of three establishment methods (Transplanting polypot (TP),Transplanting nursery (TN) and Direct Seeding (DS) and six weed management practices (Atrazine @ $1.5 \mathrm{~kg}_{\text {a.i. }} \mathrm{ha}^{-1}$ as pre emergence + hand weeding and intercultivation at 30 days after sowing (W1), Pendimethalin @ 1.0kg a.i. $\mathrm{ha}^{-1}$ as pre emergence + hand weeding and intercultivation at 30 days after sowing DAS (W2), Pendimethalin@ $1.0 \mathrm{~kg}$ a.i. $\mathrm{ha}^{-1}$ pre emergence + Sulfosulfuran $60 \mathrm{~g}$ a.i. ha ${ }^{-1}$ as post emergence at 30 DAS (W3), Atrazine @ $1.5 \mathrm{~kg}$ a.i. $\mathrm{ha}^{-1}$ as pre emergence +Tumbotrione $120 \mathrm{~g}$ a.i. ha ${ }^{-1}$ as post emergence at 30 DAS (W4), Weed free (W5), Weedy check(W6) laid out in RCBD with three replications. Sweet corn variety Sugar-75 of Syngenta was used as the test variety. The seedling parameters were significantly superior in transplanting polyplot sown in green house. All the growth parameters (viz. plant height, dry matter production, leaf area index), days to tasseling, days to silking and yield parameters viz. number of cobs plant-1, number of grains $\mathrm{cob}^{-1}$, green cob yield and stover yield and harvest index) were observed to be significantly higher in transplanting polyplot. The plant height, leaf area index, dry matter accumulation and number of leaves were observed to be significantly higher in treatment of atrazine @ $1.5 \mathrm{~kg}$ a.i. $\mathrm{ha}^{-1}$ as pre emergence + tembotrione $120 \mathrm{~g}$ a.i. ha ${ }^{-1}$ as post emergence at 30 DAS (W4). Yield parameters viz., green cob yield and green fodder yield increased significantly in treatment of atrazine @ $1.5 \mathrm{~kg}$ a.i. $\mathrm{ha}^{-1}$ as pre emergence + tembotrione $120 \mathrm{~g}$ a.i. $\mathrm{ha}^{-1}$ as post emergence at 30 DAS (W4). It can concluded that under existing conditions transplanted polypot in combination with application of atrazine @ $1.5 \mathrm{~kg} \mathrm{a.i.} \mathrm{ha}{ }^{-1}$ (pre-emergence) + tembotrione @ $120 \mathrm{~g}$ a.i. ha ${ }^{-1}$ (post-emergence) (TPW4) showed highest benefit cost ratio of 7.97 and proved superior for realizing higher yield and profitability of sweet corn under temperate conditions. 


\section{Introduction}

Sweet corn is the new age super diet for health conscious people. The nutritive value of sweet corn is comparable to several high priced vegetable like cauliflower, cabbage, french beans, fiber content and low in cholesterol (Yodpetch, 1979), it offers even greater health benefits when cooked. The Sweet corn's antioxidant activity is significantly increased when cooked, helping to battle cancer, heart disease and protect against cataracts. It is one of the most popular vegetable in the western and advanced countries of the world (ICAR, 2006). The awareness about sweet corn in Kashmir valley is also growing gradually and may increase further with the growth in tourism industry. Abundant sunshine, moderate temperature and nearly pest free environment of Kashmir valley is suited for high quality and yield of sweet corn. In Kashmir valley, due to low prevailing temperature in the month of April and May, high soil moisture due to excessive spring rainfall coupled with cutworm infestation, direct seeding often becomes a difficult as seed suffers from bird damage and poor germination resulting in loss of costly seed. Raising the seedlings in polypots root $^{-1}$ trainers under protected conditions is one of the alternatives that need to be explored.

Transplanting ensures maximum crop stand establishment, early flowering, maximum biomass production and more grain yield as compared to direct seeding. It is best method to get maximum crop plants under similar conditions. The advantages of transplanting are a reduced mortality compared with direct seeding, scope for the selection of strong and healthy seedlings to ensure a better plant stand and economies in the seed rate. In transplanting plastic plug trays are used as an alternative of direct seeding and the effect of sowing date for different sweet maize mutants has been evaluated. Sweet maize mutants hybrids Canner (sul), Butter Sweet (sh2) and Cheyenne (sel) were sown in spring and summer by direct seeded or in plastic plug trays (128 cells tray ${ }^{-1}$ ) for transplant. Present results suggest that it was possible to obtain similar or higher yield from sweet corn maize mutant plants using a transplant method than direct-seeded under optimal environments (Rattin et al., 2006).

The growth conditions can be made favourable for the crop through effective use of weed management practices. The combination of pre emergence and new post emergence herbicide with hand weeding and inter-cultivation operations need to be evaluated for their effect on sweet corn and its associated weed flora. Weed management strategies attempt to limit the deleterious effects of weeds growing with crop plants.

Therefore a field investigation on the establishment methods and weed management practices was conducted to evaluate the seedling quality and optimize the different establishment methods and weed management practices for higher growth and yield and profitability of sweet corn.

\section{Materials and Methods}

A field experiment was conducted at Faculty of Agriculture, Wadura, Sopore to investigate the response of sweet corn to establishment methods and weed management practices on the yield and quality of sweet corn. It is located at latitude of $34^{\circ} 34^{\prime} \mathrm{N}$, longitude $74^{\circ} 40^{\prime} \mathrm{E}$ and altitude of $1590 \mathrm{~m}$ amsl. The soil of the experimental field was silty clay loam in texture, neutral in reaction, low in available $\mathrm{N}(210 \mathrm{~kg} / \mathrm{ha})$ and $\mathrm{P}(12.3 \mathrm{~kg} / \mathrm{ha})$ and medium in available $\mathrm{K}(183.5 \mathrm{~kg} / \mathrm{ha})$. Treatments comprised of three establishment methods (Transplanting polypot, Transplanting nursery and Direct seeding) and six weed management practices ((Atrazine@ 
$1.5 \mathrm{~kg}$ a.i. $\mathrm{ha}^{-1}$ as pre emergence + hand weeding and intercultivation at 30 days after sowing $\left(\mathrm{W}_{1}\right)$, Pendimethalin @ 1.0kg a.i.. ha ${ }^{-1}$ as pre emergence + hand weeding and intercultivation at 30 days after sowing DAS $\left(\mathrm{W}_{2}\right)$, Pendimethalin@1.0 kg a.i.. ha ${ }^{-1}$ pre emergence + Sulfosulfuran $60 \mathrm{~g}$ a.i.. ha ${ }^{-1}$ as post emergence at 30 DAS $\left(\mathrm{W}_{3}\right)$, Atrazine @ $1.5 \mathrm{~kg}$ a.i.. $\mathrm{ha}^{-1}$ as pre emergence +Tumbotrione $120 \mathrm{~g}$ a.i. $\mathrm{ha}^{-1}$ as post emergence at 30 DAS $\left(\mathrm{W}_{4}\right)$, Weed free $\left(\mathrm{W}_{5}\right)$, Weedy check $\left(\mathrm{W}_{6}\right)$ laid out in RCBD with three replications. Sweet corn variety Sugar75 of Syngenta was used as the test variety.

The seeds were sown in greenhouse on $11^{\text {th }}$ May in transplanted polybags and transplanted nursery respectively and transplanted at an age of 20 days and sowing in main field was done at $15^{\text {th }}$ May. Seedlings were raised under protected in poly bags using potting mixture of $400 \mathrm{~g}$ of soil: sand: manure in the ratio of $2: 1: 1$.

The poly bags were teared at the time of transplanting without disturbing the soil. A spacing of $60 \mathrm{~cm} \times 20 \mathrm{~cm}$ was used, Before sowing, full dose of nitrogen, phosphorus and potassium at the rate of $120 \mathrm{~N}, 40 \mathrm{P}_{2} \mathrm{O}_{5}$ and $20 \mathrm{~K}_{2} \mathrm{O} \mathrm{kg} \mathrm{ha}{ }^{-1}$, respectively through Urea, Di-ammonium Phosphate (DAP) and Murate of Potash (MoP) was applied uniformly to each plot as basal dose.

Germination percentage and Seedling vigour was calculated as per the following formulae

Germination percentage $=$ Total number of seeds germinated/ Total number of seeds sown $\times 100$

\section{Seedling vigour index I}

Vigour index $\mathrm{I}=$ Germination $\% \times$ Seedling length

\section{Seedling vigour index II}

Vigour index II $=$ Germination $\% \times$ Seedling dry weight (Abdulbaki and Anderson, 1973).

\section{Results and Discussion}

\section{Seedling quality parameters}

All the seedling parameters viz., seedling shoot length, seedling root length, seedling fresh and dry weight, germination percentage, number of leaves, seedling vigour index I and II were found to be significantly superior in transplanted polypot (Table 1). Therefore, it is fundamental to determine the optimum temperature for the plant. Higher temperature associated with seedlings in greenhouse in polypot sowing resulted in high growth rate of the seedlings and thus higher values of various seedling parameters were obtained. Inglett (1970) and Bunting (1971) reported that most maize seed germinated slowly below $10^{\circ} \mathrm{C}$ and germination increases drastically in the higher temperature regimes. Di Benedetto et al., (2006) also reported that germination rate and emergence would be enhanced by a transplanted technique.

\section{Growth attributes}

The data pertaining to the growth parameters viz. plant height, dry matter production, leaf area index, no of functional leaves viz. were observed to be significantly higher in transplanted polypot than direct seeding and transplanting nursery (Table 2).

\section{Plant height}

Plant height is an important growth index to study the accumulation of dry matter by the plant. Plant height was significantly affected by establishment methods. There was a consistent increase in plant height of sweet corn till harvest (Table 2). Transplanted 
polypot showed highest plant height as compared to direct seeding and transplanted nursery. Direct sowing plants showed lower plant height because they entered generative earlier as of heat increase.

The results are in close conformity with those of Idikut (2013), Cesur and Tosun (2005) and Williams (2008).

\section{Number of leaves}

Number of leaves per plant at 15 days interval during crop growth was significantly influenced by establishment methods upto 45 days after sowing, transplanted polypot sowing registered more number of leaves plant $^{-1}$ due to ideal growth conditions (Table 2). Our findings are in close conformity with results of Chudasama et al., (2017).

\section{Leaf area index}

Among different establishment methods transplanted polypot showed highest leaf area index (5.71) at 60 DAS than direct seeding and transplanted nursery.

Plants transplanted with lesser aged seedlings resulted in more LAI and root volume which contributed towards increased source- sink relationship within the plants and resulted in more dry matter accumulation. The results are in confirmation with the results related reported by Town Phung (2004) and Kumar et al., (2012).

\section{Dry matter accumulation}

However, less aged seedlings in transplanted polypot (TP) resulted in more leaf area which contributed towards increased source-sink relationship and resulted in more dry matter accumulation. The results are in confirmation with the results reported by Kumar et al., (2012).

\section{Effect of weed management practices on} Growth attributes

\section{Plant height}

Weed management practices have a profound effect on plant height (Table 2). Among herbicides atrazine $1.5 \mathrm{~kg}$ a.i. ha $^{-1}$ as pre emergence + tembotrione $120 \mathrm{~g}$ a.i. $\mathrm{ha}^{-1}$ as post emergence at 30 DAS $\left(\mathrm{W}_{4}\right)$ recorded higher plant height which was at par with other treatments of herbicides as tembotrione is a selective post-emergence herbicide for the control of broad leaf and grassy weeds in maize.

The possible reason for beneficial effect could possibly be attributed to higher weed-control efficiency with these treatments resulting in more favorable environment for growth and development of crop plants apparently due to lesser weed competition which led to increase height of maize plant. Our results in conformity with the results of Singh et al., (2012).

\section{Number of leaves}

Weed management practices have a profound effect on plant height (Table 2). Among herbicides atrazine $1.5 \mathrm{~kg}$ a.i. $\mathrm{ha}^{-1}$ as pre emergence + tembotrione $120 \mathrm{~g}$ a.i. $\mathrm{ha}^{-1}$ as post emergence at 30 DAS $\left(\mathrm{W}_{4}\right)$ recorded highest number of leaves which is at par with weed free treatment $\left(\mathrm{W}_{5}\right)$ as tembotrione is broad spectrum herbicide and is effective in controlling weeds reduces crop weed competition. These results are in line with Akhtar et al., (2015).

\section{Leaf area index}

Atrazine $1.5 \mathrm{~kg}$ a.i. $\mathrm{ha}^{-1}$ as pre emergence + tembotrione $120 \mathrm{~g}$ a.i. $\mathrm{ha}^{-1}$ as post emergence at 30 DAS $\left(\mathrm{W}_{4}\right)$ recorded highest number of leaves which is at par with weed free 
treatment $\left(\mathrm{W}_{5}\right)$ and thereby increase in nutrient uptake by improving the leaf area. Similar findings were reported by Angiras and Singh (1989) and Mundra et al., (2002).

\section{Dry matter accumulation}

Dry matter accumulation of crop showed significant variation with respect to weed management practices at 15 days interval of the crop growth (Table 2).

Table.1 Effect of Establishment methods on different parameters of seedlings of sweet corn

\begin{tabular}{|c|c|c|c|c|c|c|c|c|}
\hline $\begin{array}{l}\text { Establishment } \\
\text { methods }\end{array}$ & $\begin{array}{l}\text { Shoot } \\
\text { length } \\
\text { (cm) }\end{array}$ & $\begin{array}{l}\text { Root } \\
\text { length } \\
\text { (cm) }\end{array}$ & $\begin{array}{l}\text { Fresh } \\
\text { weight } \\
\text { (g) }\end{array}$ & $\begin{array}{l}\text { Dry } \\
\text { weight } \\
\text { (g) }\end{array}$ & $\begin{array}{l}\text { Number } \\
\text { of leaves }\end{array}$ & $\begin{array}{l}\text { Germination } \\
\text { (percent) }\end{array}$ & $\begin{array}{l}\text { Vigour } \\
\text { index-I }\end{array}$ & $\begin{array}{l}\text { Vigour } \\
\text { index-II }\end{array}$ \\
\hline TP & 20.69 & 14.54 & 5.43 & 2.23 & 4.48 & 94.17 & 3198.01 & 209.99 \\
\hline $\mathbf{T N}$ & 17.44 & 11.58 & 4.15 & 1.48 & 3.77 & 87.26 & 2600.34 & 129.14 \\
\hline DS & 18.46 & 12.52 & 4.37 & 1.65 & 4.37 & 92.01 & 2850.46 & 151.81 \\
\hline SEm \pm & 0.99 & 0.96 & 0.20 & 0.08 & 0.15 & 0.71 & 79.81 & 17.03 \\
\hline $\mathrm{CD}(\mathrm{p} \leq 0.05)$ & 2.97 & 2.88 & 0.57 & 0.23 & 0.45 & 2.06 & 230.37 & 49.15 \\
\hline
\end{tabular}

Transplanting polypot: TP, Transplanting nursery: TN, Direct Seeding: DS

Table.2 Effect of establishment methods and weed management practices on growth parameters of sweet corn

\begin{tabular}{|c|c|c|c|c|}
\hline Treatments & $\begin{array}{l}\text { Plant } \\
\text { height }\end{array}$ & $\begin{array}{l}\text { Leaf } \\
\text { index }\end{array}$ & $\begin{array}{l}\text { No. } \\
\text { functional } \\
\text { leaves }\end{array}$ & $\begin{array}{l}\text { of Dry matter } \\
\text { accumulation } \\
\text { (t/ha) }\end{array}$ \\
\hline \multicolumn{5}{|c|}{ Establishment Methods } \\
\hline $\mathbf{T P}$ & 286.00 & 4.89 & 11.34 & 176.39 \\
\hline TN & 259.22 & 3.20 & 8.85 & 105.28 \\
\hline DS & 264.82 & 4.00 & 10.82 & 128.25 \\
\hline SEm \pm & 1.34 & 0.033 & 0.095 & 1.50 \\
\hline $\mathrm{CD}(\leq 0.05)$ & 3.86 & 0.09 & 0.27 & 4.35 \\
\hline \multicolumn{5}{|c|}{ Weed management } \\
\hline $\mathbf{W}_{1}$ & 269.59 & 3.83 & 9.93 & 124.27 \\
\hline $\mathbf{W}_{2}$ & 271.51 & 3.98 & 10.14 & 131.07 \\
\hline $\mathbf{W}_{3}$ & 273.67 & 4.18 & 10.40 & 136.54 \\
\hline $\mathbf{W}_{4}$ & 277.00 & 4.29 & 10.52 & 146.04 \\
\hline $\mathbf{W}_{5}$ & 288.55 & 4.32 & 10.57 & 151.47 \\
\hline $\mathrm{W}_{6}$ & 257.23 & 3.70 & 10.44 & 117.45 \\
\hline SEm \pm & 1.89 & 0.046 & 0.134 & 2.13 \\
\hline $\mathrm{CD}(\leq 0.05)$ & 5.46 & 0.13 & 0.39 & 6.15 \\
\hline
\end{tabular}

Transplanting polypot: TP, Transplanting nursery: TN, Direct Seeding: DS, $\mathrm{W}_{1}$ : Atrazine @ $1.5 \mathrm{~kg}$ a.i ha ${ }^{-1}$ as PRE+Hand weeding (HW) + IC (Intercultivation) at 30DAS, $\mathrm{W}_{2}$ : Pendamethalin @ $1.0 \mathrm{~kg} a . i \mathrm{ha}^{-1}$ as PRE + HW + IC at 30 DAS, $\mathrm{W}_{3}$ : Pendamethalin @ $1.0 \mathrm{~kg} \mathrm{ha}^{-1}$ as PRE+ Sulfosulfuron $60 \mathrm{~g}$ a. $i \mathrm{ha}^{-1}$ as post at $30 \mathrm{DAS}, \mathrm{W}_{4}$ : Atrazine @ 1.5kg a.i ha ${ }^{-1}$ PRE +Tembotrione @ $120 \mathrm{~g} \mathrm{ha}^{-1}$ as post emergence at $30 \mathrm{DAS}, \mathrm{W}_{5}$ : Weed free, $\mathrm{W}_{6}$ : Weedy check. 
Table.3 Effect of Establishment methods and weed management practices on number of cobs plant-1, number of rows $\mathrm{cob}^{-1}$, number of grains row $^{-1}$, number of grains $\mathrm{cob}^{-1}, \mathrm{Cob}$ length $(\mathrm{cm})$,

Cob girth $(\mathrm{cm})$ at different growth stages of sweet corn

\begin{tabular}{|c|c|c|c|c|c|c|c|c|}
\hline \multirow[t]{2}{*}{ Treatment } & \multirow{2}{*}{$\begin{array}{l}\text { No of } \\
\text { cobs } \\
\text { plant }^{-1}\end{array}$} & \multirow{2}{*}{$\begin{array}{l}\text { No of } \\
\text { rows } \\
\text { cob }^{-1}\end{array}$} & \multirow{2}{*}{$\begin{array}{l}\text { No of } \\
\text { grains } \\
\text { row }^{-1}\end{array}$} & \multirow{2}{*}{$\begin{array}{l}\text { Number } \\
\text { of grains } \\
\text { per } \text { cob }^{-1}\end{array}$} & \multicolumn{2}{|c|}{ Cob length $(\mathrm{cm})$} & \multicolumn{2}{|c|}{ Cob girth (cm) } \\
\hline & & & & & $\begin{array}{l}\text { With } \\
\text { husk }\end{array}$ & $\begin{array}{l}\text { Without } \\
\text { husk }\end{array}$ & $\begin{array}{l}\text { With } \\
\text { husk }\end{array}$ & $\begin{array}{l}\text { Without } \\
\text { husk }\end{array}$ \\
\hline \multicolumn{9}{|c|}{ Establishment methods } \\
\hline TP & 1.83 & 18.12 & 26.58 & 486.33 & 29.61 & 26.61 & 18.40 & 15.21 \\
\hline $\mathbf{T N}$ & 1.07 & 17.00 & 20.58 & 334.58 & 23.05 & 20.05 & 16.29 & 13.09 \\
\hline DS & 1.28 & 17.51 & 23.35 & 414.91 & 27.22 & 23.72 & 17.25 & 13.99 \\
\hline SEm \pm & 0.02 & 0.11 & 0.31 & 6.93 & 0.48 & 0.47 & 0.06 & 0.05 \\
\hline $\mathrm{CD}(\mathrm{P} \leq 0.05)$ & 0.06 & 0.34 & 0.89 & 20.09 & 1.39 & 1.36 & 0.17 & 0.16 \\
\hline \multicolumn{9}{|c|}{ Weed management } \\
\hline $\mathbf{W}_{1}$ & 1.31 & 17.06 & 21.55 & 369.35 & 25.11 & 22.00 & 16.77 & 13.58 \\
\hline $\mathbf{W}_{2}$ & 1.36 & 17.36 & 23.50 & 410.70 & 26.11 & 22.77 & 17.28 & 14.08 \\
\hline $\mathbf{W}_{3}$ & 1.41 & 18.20 & 24.04 & 438.71 & 27.66 & 24.55 & 17.54 & 14.34 \\
\hline $\mathbf{W}_{4}$ & 1.50 & 18.60 & 25.28 & 472.32 & 29.11 & 26.00 & 18.04 & 14.81 \\
\hline$W_{5}$ & 1.54 & 18.71 & 26.25 & 492.26 & 29.89 & 26.67 & 18.36 & 15.16 \\
\hline$W_{6}$ & 1.25 & 15.33 & 19.89 & 305.13 & 21.89 & 18.77 & 15.86 & 12.60 \\
\hline SEm \pm & 0.03 & 0.16 & 0.44 & 9.80 & 0.68 & 0.68 & 0.08 & 0.08 \\
\hline $\mathrm{CD}(\mathrm{P} \leq 0.05)$ & 0.09 & 0.48 & 1.26 & 28.31 & 1.97 & 1.93 & 0.24 & 0.23 \\
\hline
\end{tabular}

Transplanting polypot: TP, Transplanting nursery: TN, Direct Seeding: DS, $\mathrm{W}_{1}$ : Atrazine@ $1.5 \mathrm{~kg} a . i \mathrm{ha}^{-1}$ as PRE+Hand weeding (HW) + IC (Intercultivation) at 30DAS, $\mathrm{W}_{2}$ : Pendamethalin @ $1.0 \mathrm{~kg} a . i \mathrm{ha}^{-1}$ as PRE + HW + IC at $30 \mathrm{DAS}, \mathrm{W}_{3}$ : Pendamethalin @ $1.0 \mathrm{~kg} \mathrm{ha}^{-1}$ as PRE+ Sulfosulfuron $60 \mathrm{~g}$ a.i ha ${ }^{-1}$ as post at 30DAS, $\mathrm{W}_{4}$ : Atrazine @ $1.5 \mathrm{~kg}$ a.i $\mathrm{ha}^{-1} \mathrm{PRE}+$ Tembotrione @ $120 \mathrm{~g} \mathrm{ha}^{-1}$ as post emergence at $30 \mathrm{DAS}, \mathrm{W}_{5}$ : Weed free, $\mathrm{W}_{6}$ : Weedy check

Table.4 Effect of establishment methods and weed management practices on weight cob $^{-1}$ (with and without husk), husk corn ratio

\begin{tabular}{|l|l|l|l|}
\hline \multirow{2}{*}{ Treatment } & \multicolumn{2}{|l|}{ Cob weight(gram) } & Husk:corn ratio \\
\cline { 2 - 3 } & With husk & Without husk & \\
\hline TP & 397.77 & 377.00 & 1.32 \\
\hline TN & 295.55 & 275.00 & 1.17 \\
\hline DS & 353.44 & 326.38 & 1.22 \\
\hline SEm \pm & $\mathbf{7 . 9 4}$ & $\mathbf{5 . 2 3}$ & $\mathbf{0 . 0 2 8}$ \\
\hline CD $(\mathbf{P} \leq \mathbf{0 . 0 5})$ & $\mathbf{2 2 . 9 2}$ & $\mathbf{1 5 . 0 7}$ & $\mathbf{0 . 0 8}$ \\
\hline $\mathbf{W}_{\mathbf{1}}$ & 338.11 & 318.00 & 1.23 \\
\hline $\mathbf{W}_{\mathbf{2}}$ & 343.77 & 324.00 & 1.24 \\
\hline $\mathbf{W}_{\mathbf{3}}$ & 361.88 & 343.00 & 1.25 \\
\hline $\mathbf{W}_{\mathbf{4}}$ & 377.33 & 357.33 & 1.26 \\
\hline $\mathbf{W}_{\mathbf{5}}$ & 400.88 & 382.55 & 1.27 \\
\hline $\mathbf{W}_{\mathbf{6}}$ & 283.55 & 231.88 & 1.18 \\
\hline SEm \pm & $\mathbf{1 1 . 2 3}$ & $\mathbf{1 5 . 1 0}$ & $\mathbf{0 . 0 4 0}$ \\
\hline CD $(\mathbf{P} \leq \mathbf{0 . 0 5})$ & $\mathbf{3 2 . 4 1}$ & $\mathbf{4 5 . 0 1}$ & NS \\
\hline
\end{tabular}

Transplanting polypot: TP, Transplanting nursery: TN, Direct Seeding: DS, $\mathrm{W}_{1}$ : Atrazine @ $1.5 \mathrm{~kg}$ a.i ha ${ }^{-1}$ as PRE+Hand weeding (HW) + IC (Intercultivation) at 30DAS, $\mathrm{W}_{2}$ : Pendamethalin @ $1.0 \mathrm{~kg} a . i \mathrm{ha}^{-1}$ as PRE + HW + $\mathrm{IC}$ at $30 \mathrm{DAS}, \mathrm{W}_{3}$ : Pendamethalin @ $1.0 \mathrm{~kg} \mathrm{ha}^{-1}$ as PRE+ Sulfosulfuron $60 \mathrm{~g}$ a.i $\mathrm{ha}^{-1}$ as post at $30 \mathrm{DAS}, \mathrm{W}_{4}$ : Atrazine @ $1.5 \mathrm{~kg}$ a.i ha ${ }^{-1}$ PRE +Tembotrione @ $120 \mathrm{~g} \mathrm{ha}^{-1}$ as post emergence at 30 DAS, $\mathrm{W}_{5}$ : Weed free, $\mathrm{W}_{6}$ : Weedy check 
Fig.1 Effect of establishment methods on green cob yield at harvest stages of sweet corn

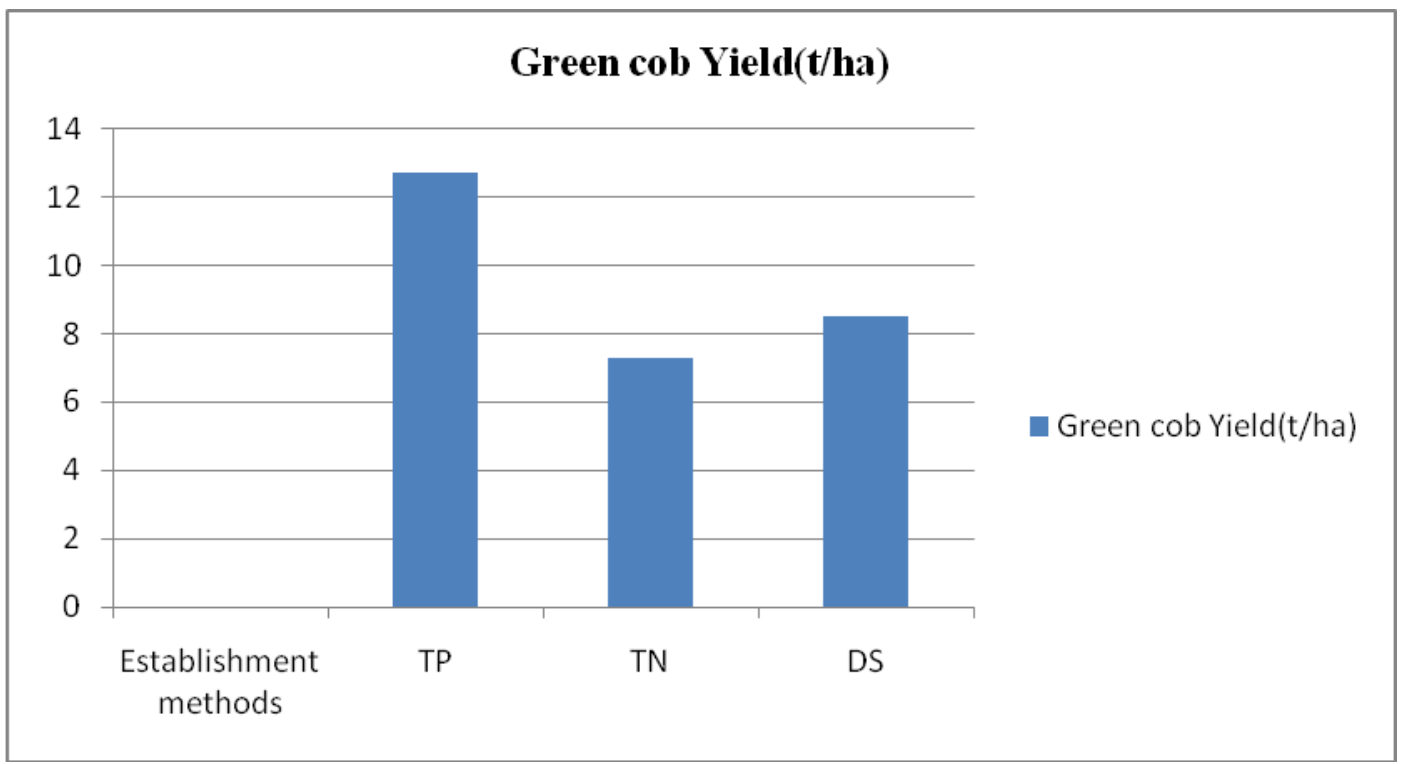

Fig.2 Effect of weed management practices on green cob yield at harvest stage of sweet corn

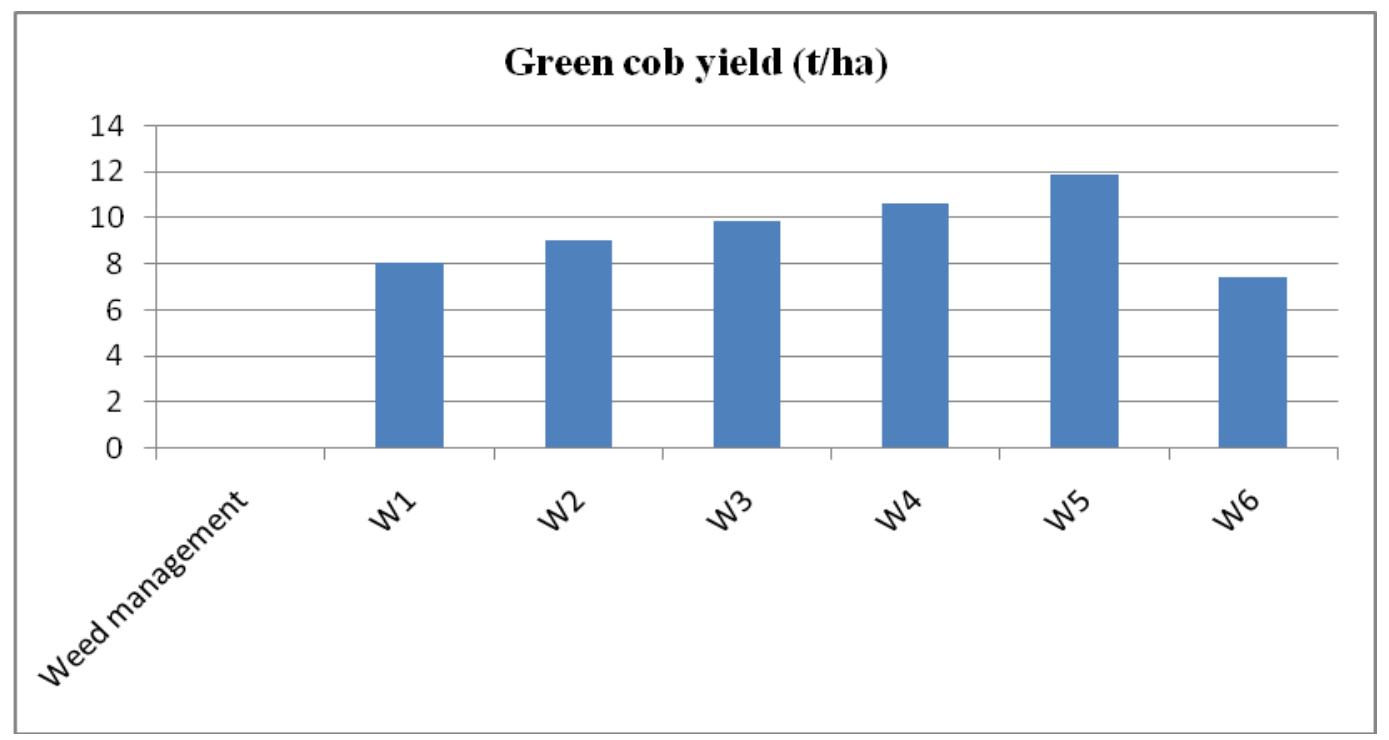

Atrazine $1.5 \mathrm{~kg}$ a.i. $\mathrm{ha}^{-1}$ as pre emergence + tembotrione $120 \mathrm{~g}$ a.i. ha $^{-1}$ as post emergence at 30 DAS $\left(\mathrm{W}_{4}\right)$ recorded highest dry matter accumulation which is at par with weed free treatment $\left(\mathrm{w}_{5}\right)$ it might be due to atrazine as pre emergence along with tembotrione as post emergence resulted in excellent control of grassy weeds and thereby results increase in nutrient uptake by improving the leaf area, and more leaf area contributed increased source sink relationship and in this way resulted more dry matter accumulation (Akhtar et al., 2015).

Yield and yield attributes influenced by establishment methods

Yield viz. number of grains/cob, cobs/plant, cob length and cob girth was significantly higher in transplanted polypot. Maximum cob length, number of grains $\mathrm{cob}^{-1}$, cobs plant ${ }^{-1}$ and cob girth, cob weight (with and without husk) was recorded in transplanted polypot (Table 4). 
Three weeks old seedling recorded significantly maximum number of cob length, cob girth, cob weight and grains $\operatorname{cob}^{-1}$ as due to high dry matter accumulation in transplanted polypots resulting in increased yield attributes.

Similarly (green cob yield, green fodder yield and harvest index) were observed to be significantly higher in transplanting polypot (Fig. 1 and Table 4). The increase in grain yield (green cob yield) could be attributed to higher yield attributes and increase in biological yield might be due to higher leaf area index and dry matter accumulation. Among establishment methods transplanted polyplot show highest grain yield as compared to direct seeding and transplanted nursery. Seedlings raised in green-house planted in the field during or after the optimum time matured earlier and could give higher grain yields than direct seeded maize. Higher values for yield attributes of transplanted polypot ascribed to higher LAI, dry matter production as well as translocation and conversion of photosynthesis into reproductive parts due to more root volume. The results are in accordance with the results of Kumar et al., (2014) and Dhillon et al., (1990).

\section{Yield and yield attributes influenced by weed management practices}

Yield contributing characters viz. number of cobs plant ${ }^{-1}$, cob length, rows $\operatorname{cob}^{-1}$ and grains row $^{-1}$ varied significantly amongst different weed management practices (Table 3 ). Atrazine $1.5 \mathrm{~kg} \mathrm{ha}^{-1}$ pre emergence + tembotrione $120 \mathrm{~g}$ $\mathrm{ha}^{-1}$ as post emergence at 30 DAS $\left(\mathrm{W}_{4}\right)$ at par with weed free $\left(\mathrm{W}_{5}\right)$ reported significantly higher green and stover yield due to higher leaf area index, which resulted in more dry matter accumulation and which in turn translocated to sink in $\left(\mathrm{W}_{4}\right)$ treatment (Fig. 2 and Table 4). These results are also in close agreement with previous findings of Dixit and Gautam, (1994) and Martin et al., (2011).

\section{Relative economics}

In present investigation it was observed that transplanting polyplot with atrazine @ $1.5 \mathrm{~kg}$ a.i. $\mathrm{ha}^{-1}$ as pre + tembotrione $120 \mathrm{~g}$ a.i. $\mathrm{ha}^{-1}$ as post emergence at 30 DAS recorded higher net returns and benefit cost ratio ₹ 542230 and 7.97, respectively. The reason was higher number of cobs and green fodder yield in this treatment combination than others without any addition in cost of cultivation. The results are in line with those of the results reported by (Triveni et al., (2017).

It may be concluded that transplanting polypot in combination with atrazine @ $1.5 \mathrm{~kg}$ a.i. ha ${ }^{-1}$ (pre-emergence) + tembotrione @ $120 \mathrm{~g}$ a.i. ha ${ }^{-}$ 1 (post-emergence) produced significantly higher grain and fodder yield.

\section{References}

Abdulbaki, A.A., and Anderson, J.D. 1973. Vigour determination in soybean seed by multiple criteria. Crop Science. 13: 630-633.

Akhtar, P., Kumar, A., Kumar, J., Sharma, A. K. and Bharti, V. 2015. Efficacy of tembotrione on mixed weed flora and yield of spring maize under irrigated subtropical shiwalik foothills $25^{\text {th }}$ AsianPacific Weed Science Society Conference on "Weed Science for Sustainable Agriculture, Environment and Biodiversity pp. 266.

Angiras, N. N. and Singh, C. M. 1989. Effect of weed control methods, cropping systems, plant population and soil fertility levels on nutrient removal and soil fertility status of maize yield. Indian Journal of Weed Science 21(1-2): 69-74.

Bunting, E. S. 1971. Plant density and yield of shoot dry material in maize in England. Journal of Agricultural Science 77: 175185.

Cesur, C. and Tosun, S. 2005. Effect of planting dates and growing techniques on green yield and some characters of sweet corn. $K S U$ Journal of Science and Engineering 8(1): 91-100.

Chudasama., V. N. Patel., V. J. Patel, P. K. and 
Patel., B. D. 2017. Feasibility of transplanting Rabi maize (Zea mays L.) varieties to varying age of seedling under middle Gujarat conditions. Journal of Pharmacognosy and Phytochemistry 6(5): 34-37.

Dhillon, B. S., Khehra, A. S., Brar, H. S., Sharma, R. K. and Malhotra, V. V. 1990. Transplanting of maize during the winter in India. Agronomy Journal 82: 41-47.

Di-Benedetto, A., Molinari. J. and Rattin, J. 2006. The effect of transplant in sweet maize (Zea mays) II. Container root restriction. International Journal of Agricultural Research 1: 555-563.

ICAR. 2006. Hand Book of Agriculture. ICAR Publication pp. 886.

Idikut, L. 2013. The effects of light, temperature and salinity on seed germination of three maize forms. Greener Journal of Agriculture Science 3: 246-253.

Inglett, G. E. 1970. Corn culture, processing and products. AVI Publishing Corporation, London, England pp. 360.

Kumar, S. and Shivani, K. S. 2014. Performance of transplanted maize (Zea mays) under varying age of seedling and method of nursery raising in the midlands of eastern region., Indian Journal of Agricultural Sciences 84(7): 877-882.

Kumar, S., Shivani, M. K., Meena, M. K. and Singh, S. S. 2012. Production potential and plant water status in transplanted maize (Zea mays L.) as influenced by methods of seedling raising and age of seedling under irrigated midlands of
Eastern India. International Journal of Agricultural and Statistical Sciences 8(2): 697-704.

Mundra, S. L., Vyas, A. K. and Maliwal, P. L. 2002. Effect of weed and nutrient management on nutrient uptake by maize (Zea mays L.) and weed. Indian Journal of Agronomy 47(3): 378-383.

Rattin, J., Benedetto, Di, A. and Gornatti, T. 2006. The effect of transplant in sweet maize (Zea mays). I. Growth and Yield. International journal of Agricultural Research 1: 58-67.

Singh, V. P., Guru, S. K., Kumar, A. Banga, A. and Tripathi, N. 2012. Bioefficacy of tembotrione against mixed weed complex in maize. Indian Journal of Weed Science 44(1): 1-5. Town, P. 2004. Transplanting maize on wetland. FFTC Publication Database. Springer Link-Journal article.

Town Phung. 2004. Transplanting maize on wetland. FFTC Publication Database. Springer Link- Journal article.

Triveni, U., Rani, Y. S., Patro T. S. S. K. and Bharathalakshmi, M. 2017. Effect of different pre-and post-emergence herbicides on weed control, productivity and economics of maize. Indian Journal of Weed Science 49(3): 231-235.

Williams, M. M. 2008. Sweet corn growth and yield responses to planting dates of the north central United States. Horticulture Science 43: 1775-1779.

Yodpetch, C. 1979. Studies on sweet corn as potential young cob corn (Zea mays L.). Ph.D. Thesis, Philippines.

\section{How to cite this article:}

Shayista Fayaz, Nazir Ahmad Teeli, Ashaq Hussain, Manzoor A. Ganai, Shakeel Ahmad Mir and Zahoor A. Baba. 2019. Response of Sweet Corn Hybrid to Establishment Methods and Weed Management Practices under Temperate Conditions. Int.J.Curr.Microbiol.App.Sci. 8(02): 13011309. doi: https://doi.org/10.20546/ijcmas.2019.802.152 